\title{
Potensi sumber air dan kearifan masyarakat dalam menghadapi risiko kekeringan di wilayah karst (Kabupaten Gunung Kidul, Provinsi Yogyakarta)
}

\author{
J. Nugroho ${ }^{1 *}$, M. Zid ${ }^{1}$, M. Miarsyah ${ }^{1}$ \\ 1Universitas Negeri Jakarta, Jakarta, Indonesia
}

\begin{abstract}
Abstrak.
Air merupakan salah satu kebutuhan pokok hidup. Kekurangan air dalam jangka panjang dapat menimbulkan bencana. Kekeringan merupakan salah satu bencana alam yang umumnya terjadi akibat berkurangnya curah hujan dan struktur geologis tanah. Kabupaten Gunung Kidul merupakan daerah yang sering mengalami kekeringan karena struktur geologis tanah yang berupa karst. Penelitian ini bertujuan membahas upaya-upaya yang dilakukan untuk menurunkan risiko terjadinya kekeringan di Kabupaten Gunung Kidul, Yogyakarta. Penelitian ini menggunakan metode deskriptif dengan pendekatan studi literatur. Hasil penelitian menunjukkan beberapa upaya yang dapat diterapkan untuk meminimalkan risiko kekeringan yaitu membuat sumur yang sumber airnya berasal dari sungai bawah tanah, memanfaatkan sumber mata air dan membuat penampungan air hujan (PAH).
\end{abstract}

\begin{abstract}
.
Water is one of the main needs of life. Long term water shortages can cause disasters. Drought is one of the most common natural disasters that occur due to reduced rainfall and the geological structure of the soil. Gunung Kidul Regency is an area that often experiences drought due to geological soil structure in the form of karst. This study aimed to discuss the efforts undertaken to reduce the risk of drought in the Gunung Kidul Regency, Yogyakarta. This research used descriptive method with literature study approach. The results showed several efforts that could be implemented to minimize the risk of drought, namely making wells whose water sources come from underground rivers, utilizing springs and constructing rainwater reservoirs.
\end{abstract}

Keywords: karst, drought, water sources

Kata kunci: karst, kekeringan, sumber air

\section{PENDAHULUAN}

Ketersediaan air di suatu wilayah merupakan hal penting untuk menunjang berbagai aktivitas manusia sehari-hari. Musim kemarau yang berkepanjangan menyebabkan terjadinya kekeringan, karena jumlah cadangan air tanah akan habis oleh evaporasi, transpirasi, serta penggunaan oleh manusia. Kekeringan merupakan keadaan kekurangan pasokan air pada suatu daerah dalam waktu berkepanjangan yang biasanya terjadi lebih dari satu musim dalam waktu normal, serta dapat menyebabkan gangguan pada berbagai kegiatan manusia dan lingkungan (Wilhite and Svoboda 2000 dalam UNDP 2011).

Menurut Wilhite (2000), kekeringan sebagai bencana alam berbeda dari bahaya alam lainnya. Perbedaan tersebut antara lain karena awal dan akhir kekeringan yang sulit ditentukan, hal ini disebabkan bencana kekeringan berjalan secara perlahan dan terakumulasi pada jangka waktu yang panjang. Pada bencana kekeringan terjadi kesulitan penetapan batasan definisi umum dari kekeringan yang disebabkan tidak adanya batasan yang jelas pada jangka waktu kekeringan. Oleh karena itu, kekeringan biasa dikatakan sebagai

\footnotetext{
* Korespondensi Penulis

Email : nugrohojuliadi@gmail.com
} 
fenomena merayap. Bencana kekeringan juga bersifat non struktural, daerah terdampaknya lebih luas dibandingkan bencana alam lainnya. Salah satu daerah yang rawan mengalami kekeringan saat musim kemarau adalah daerah karst.

Karst merupakan suatu kawasan yang memiliki kekhasan karena tersusun atas batuan gamping $\left(\mathrm{CaCO}_{3}\right)$ yang mudah mengalami pelarutan kimia oleh air hujan yang bersifat asam (Haryono 2008 dalam Suryanti et al. 2010). Pelarutan kimia pada batu gamping merupakan reaksi pembentukan asam karbonat $\left(\mathrm{H}_{2} \mathrm{CO}_{3}\right)$ dari air hujan dan gas $\mathrm{CO}_{2}$ di udara (White 1988). Pelarutan yang terjadi secara terus menerus dalam jangka waktu yang lama akan membentuk bentang alam di permukaan (eksokarst) dan di dalam permukaan (endokarst). Akibat proses pelarutan akan terbentuk lorong-lorong secara vertikal dan horizontal dengan berbagai variasi ukuran dan bentuk yang saling terhubung, disebut sebagai sistem perguaan (Cave System) atau drainase bawah tanah. Pada kawasan karst, air hujan sulit tertampung di tanah dan masuk melalui ponor (lubang yang memiliki aliran di bawah tanah), terkumpul pada drainase bawah tanah/sungai bawah tanah (Karunia et al. 2012). Menurut Faizal et al. (2017), kedalaman sungai bawah tanah bervariasi antara $77 \mathrm{~m}$ sampai $148 \mathrm{~m}$. Keberadaan sungai bawah tanah yang cukup dalam menyebabkan proses pengambilan air cukup sulit sehingga dibutuhkan alat khusus.

Masyarakat di daerah terdampak kekeringan khususnya kawasan karst dapat melakukan berbagai adaptasi perilaku dalam rangka menghemat air pada saat musim kemarau. Salah satu cara adalah dengan mandi sekali sehari menggunakan air hangat, karena cenderung lebih sedikit menghabiskan volume air dibandingkan menggunakan air dingin.

Hal lain yang tidak kalah penting adalah pendekatan kearifan lokal. Peraturan berbasis kearifan lokal biasanya lebih efektif diterapkan pada masyarakat tradisional yang masih memegang kuat nilai budaya lokal. Salah satu contoh kearifan lokal adalah tradisi upacara adat sebagai wujud rasa syukur dan penghormatan terhadap kesakralan sumber air. Berbagai bentuk upacara adat diantaranya kirab, kenduri atau wewayangan. Bentuk lainnya seperti cerita atau mitos mengenai keangkeran lokasi sumber air, yang membuat orang takut dan akhirnya tidak berbuat sembarangan di lokasi tersebut.

Penelitian ini berfokus pada wilayah Gunung Kidul, Provinsi Daerah Istimewa Yogyakarta yang merupakan daerah karst. Penelitian membahas strategi yang dilakukan pemerintah dan kearifan lokal yang dimiliki oleh warga masyarakat dalam meminimalkan dampak kekeringan.

\section{METODOLOGI}

Penelitian dilakukan pada bulan Desember 2019 dan difokuskan di Kabupaten Gunung Kidul, Provinsi Daerah Istimewa Yogyakarta menggunakan 
desain penelitian kualitatif dengan pendekatan kepustakaan dan hasil wawancara dengan ahli geologi. Analisis dilakukan dengan menghubungkan temuan di lapangan dengan informasi dari penelitian sebelumnya yang berhubungan dengan topik penelitian.

\section{HASIL DAN PEMBAHASAN}

\subsection{Deskripsi wilayah karst Gunung Kidul}

Kabupaten Gunung Kidul merupakan salah satu kabupaten yang terdapat di Daerah Istimewa Yogyakarta, dengan pusat pemerintahan berada di Wonosari yang letaknya $39 \mathrm{~km}$ sebelah tenggara Kota Yogyakarta. Wilayah Kabupaten Gunung Kidul termasuk daerah beriklim tropis, dengan topografi wilayah yang didominasi kawasan perbukitan karst yang sulit menyimpan air tanah, serta terdapat gua-gua alam dan sungai bawah tanah yang mengalir. Kondisi tersebut menyebabkan lahan kurang subur, kering dan tandus. Sebagai contoh, daerah Kecamatan Panggang memiliki curah hujan cukup tinggi berkisar 1875-2125 $\mathrm{mm} /$ tahun, namun tingginya curah hujan ini tidak dapat dimanfaatkan sebagai simpanan air tanah karena merupakan daerah perbukitan karst yang tidak dapat menyimpan air. Daerah yang rawan mengalami kekeringan antara lain Kecamatan Panggang, Tanjung Sari, Giriumbo, Purwosari, Paliyan, Rongkop, Semanu dan Patuk.

Faktor iklim sangat mempengaruhi kondisi alam dan kehidupan masyarakat Gunung Kidul yang sebagian besar merupakan petani. Ekosistem karst Gunung Kidul mempunyai lapisan tanah sangat tipis dan miskin hara. Vegetasi yang hidup biasanya merupakan tumbuhan yang sangat bergantung pada curah hujan. Para petani akan mulai melakukan aktivitas pertaniannya saat hujan mulai turun, hal itu karena kebanyakan pertanian di daerah Gunung Kidul merupakan sawah tadah hujan. Walaupun kebanyakan petani menanam jenis padi segreng yang cukup tahan terhadap kering, namun padi jenis ini hasil produksinya lebih rendah daripada jenis padi lainnya.

Menurut Badan Penanggulangan Bencana Daerah Kabupaten Gunung Kidul, pada tahun 2019 terdapat 15 kecamatan yang terdampak kekeringan meliputi Kecamatan Rongkop, Girisubo, Tepus, Purwosari, Panggang, Nglipar, Patuk, Ngawen, Ponjong, Semin, Semanu, Peliyan, Karangmojo, Tanjungsari dan Gedangsari (Suarajogja.id 2019). Musim kemarau yang panjang dan struktur perbukitan karst yang sulit menyimpan air menjadi penyebab utama kekeringan di daerah-daerah tersebut.

\subsection{Potensi air permukaan wilayah Gunung Kidul}

Keberadaan air permukaan jarang ditemukan di daerah karst, karena sebagian besar air hujan yang jatuh akan masuk ke dalam tanah melalui rongga- 
rongga atau diaklas, sehingga yang berkembang adalah sistem sungai bawah tanah. Penampung air pada daerah karst terbentuk dari lembah dolina yang tertutup oleh lapisan tanah terrarosa (kedap air) pada bagian dasarnya, sehingga memiliki kemampuan untuk menampung air hujan dalam jumlah atau volume tertentu (Sunarto 1977).

Pada daerah karst, air permukaan dijumpai pada telaga dan sungai permukaan dalam jumlah yang relatif kecil. Volume air yang mampu ditampung di dalam telaga dan sungai dapat menunjukkan jumlah cadangan air permukaan yang ada di daerah karst. Potensi air sungai permukaan di Kabupaten Gunung Kidul sangat rendah, karena air yang muncul dari suatu mata air dan air hujan yang jatuh di atas permukaan tanah akan segera meresap ke dalam tanah yang kemudian membentuk sistem sungai bawah tanah.

Pada tahun 2019, diketahui terdapat 460 Telaga di daerah Gunung Kidul dan 355 diantaranya dalam kondisi kering (Antara News Yogyakarta 2019). Jumlah telaga yang masih memiliki air hanya 105 buah dengan letak yang tersebar serta ukuran dan bentuk yang bervariasi. Jumlah air yang terdapat di telaga tidak mampu memenuhi kebutuhan seluruh warga masyarakat sekitar terutama di musim kemarau.

\subsection{Sumber daya air bawah tanah}

Keberadaan air tanah di daerah karst umumnya memiliki sifat khas, karena lokasinya terletak pada rongga/celah/retakan batuan, gua atau sungai bawah tanah yang menyebar secara tidak menentu, bergantung pada proses pelarutan batu gamping di daerah tersebut. Adanya kondisi tersebut menyebabkan pembuatan atau penggalian sumur gali tidak bisa dengan mudah dan secara tepat ditujukan pada sumber aliran sungai bawah tanah. Jika sumur yang dibuat menembus suatu rongga/celah/retakan batuan yang terhubung dengan aliran sungai bawah tanah, maka kemungkinan akan berhasil diperoleh air dalam jumlah yang besar.

Gunung Kidul memiliki tiga sistem sungai bawah besar yakni sistem Sundak, Bribin-Baron dan Ngobaran. Dari ketiga sistem tersebut, Gua BribinBaron dan Gua Ngobaran sudah dimanfaatkan, dengan membuat bendungan dan airnya dipompa untuk didistribusikan ke sebagian daerah Gunung Kidul. Sistem sungai bawah tanah Bribin-Baron mempunyai tiga karakteristik yang khas dari akuifer karst yaitu saluran (conduit), celah (fisure) dan rembesan (difuse). Setiap sistem sungai bawah tanah terbagi menjadi beberapa sub sistem yang mempunyai potensi sumber air sebagai mana hasil penelitian Sir MacDonald and Partners (1979) yang memetakan 266 saluran bawah tanah di Gunung Kidul dan 42 saluran diantaranya berpotensi sebagai sumber air. 
Variasi curah hujan mempengaruhi volume dan kualitas air sungai bawah tanah yang merupakan pemasok air utama. Pada musim kemarau, air bawah tanah cenderung memiliki kandungan $\mathrm{CaCO}_{3}$ lebih tinggi dibandingkan musim hujan, sehingga perlu dilakukan pengolahan lebih lanjut agar kualitas airnya memadai. Variasi temporal hujan juga akan memberikan efek pada pembentukan lapisan rongga sungai bawah tanah. Pembentukan rongga bawah tanah berpeluang memiliki kandungan air dan dapat mengalirkan air (akuifer). Pemanfaatan air dari sungai bawah tanah memerlukan pompa yang sangat kuat, untuk mengalirkan air ke bagian dataran yang paling tinggi dan selanjutnya untuk didistribusikan kepada masyarakat. Hal ini karena kedalaman sungai bawah tanah dapat mencapai ratusan meter. Pada pelaksanaannya daya yang dibutuhkan cukup besar, sehingga pemerintah membuat alternatif untuk memangkas biaya dengan membentuk bendungan bawah tanah contohnya pada sungai bawah tanah Bribin (Gambar 1).

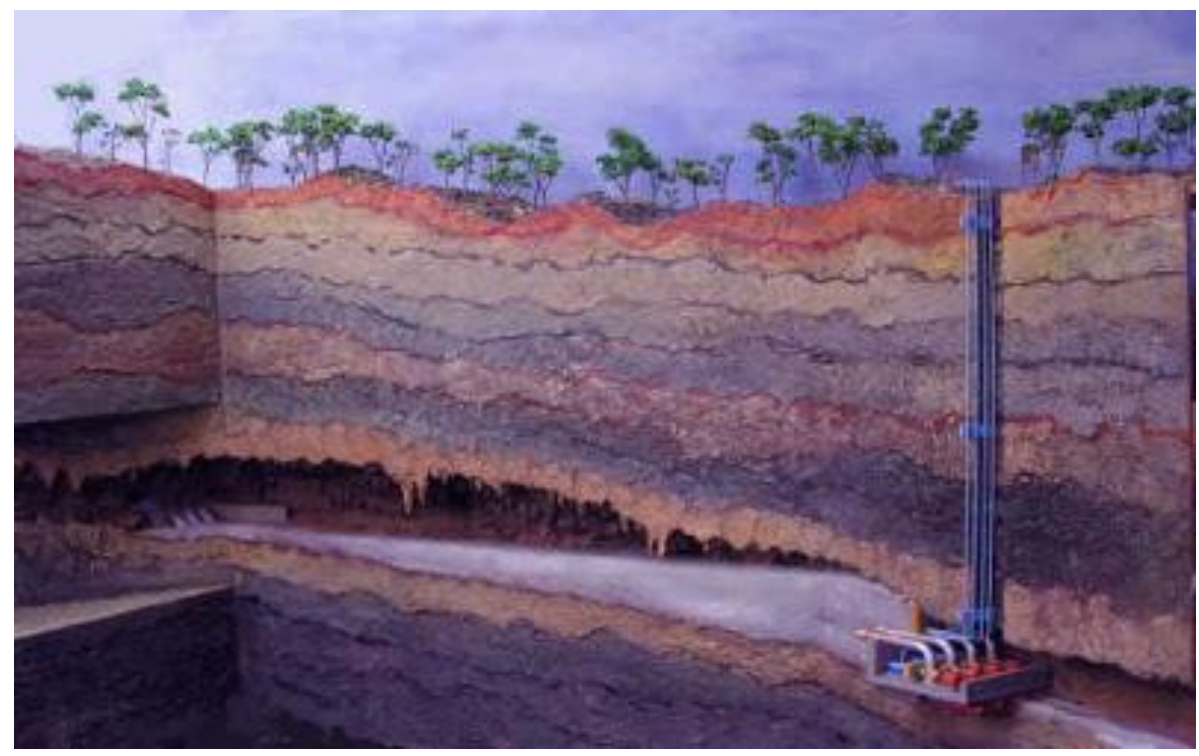

Gambar 1. Bendungan sungai bawah tanah Bribin.

Di Gunung kidul terdapat pula Sungai Bawah tanah Baron yang bermuara ke laut. Sungai bawah tanah Baron memiliki potensi yang cukup besar untuk dimanfaatkan sebagai sumber air pada musim kemarau. Menurut BBWS Serayu Opak (2019), sungai bawah Tanah Baron memiliki potensi sebesar 800 l/detik. Pengambilan air sungai bawah tanah Baron dilakukan pada daerah dekat muara sungai yang berada di pantai Baron. Pengambilan air menggunakan pompa besar hasil kerja sama antara pemerintah Jepang dengan pemerintah Indonesia (Gambar 2). 


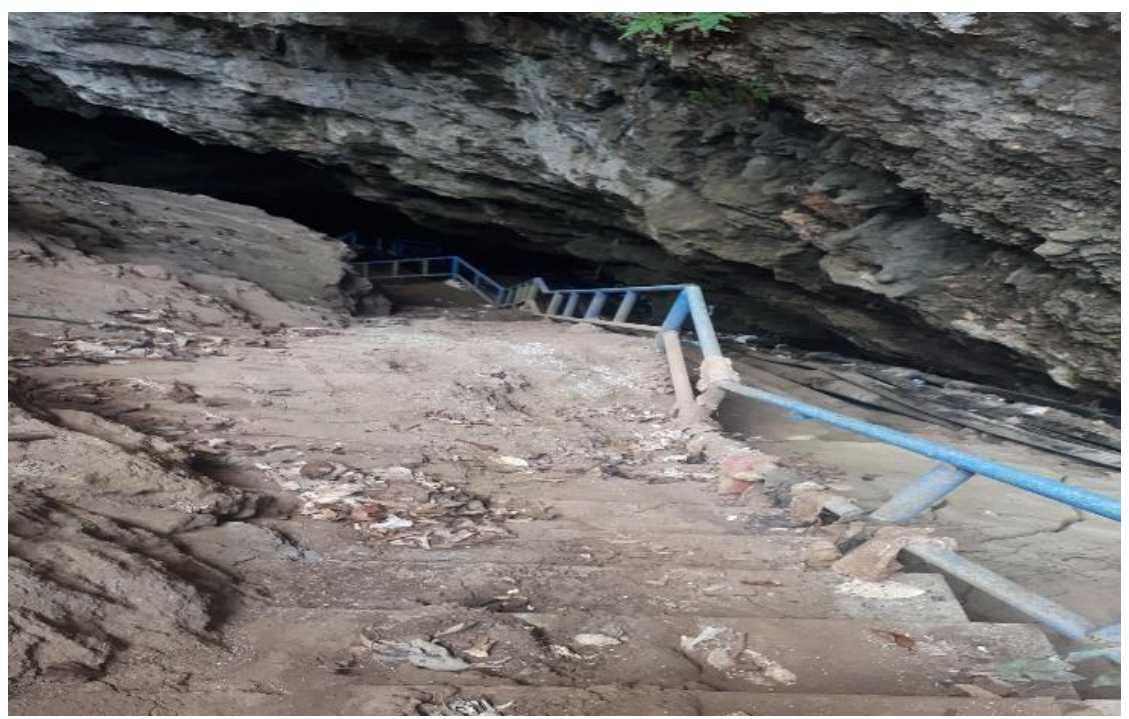

Gambar 2. Jalan menuju bendungan sungai bawah tanah Baron.

\subsection{Jenis air bawah tanah}

Mata air merupakan keadaan alami, yakni air tanah mengalir keluar dari akuifer menuju permukaan tanah. Munculnya mata air ke permukaan tanah dipengaruhi oleh kondisi geologi. Kemunculan mata air di daerah karst tidak merata, hanya terkonsentrasi di beberapa titik saja. Salah satu daerah yang memiliki potensi mata air di Kabupaten Gunung Kidul adalah Kecamatan Panggang, terletak di bagian selatan. Sumber air dari Kecamatan Panggang dimanfaatkan tidak hanya terbatas oleh warga Kecamatan Panggang, namun dimanfaatkan pula oleh kecamatan-kecamatan di sekitarnya.

Terdapat 11 mata air di Kecamatan Panggang yang tersebar secara tidak merata yaitu mata air Kaligede dan Sendangmulyo di Desa Giriharjo, mata air Bibal, Sumber, Keluwih, Beji, Sanglor dan Mbelik di Desa Girisuko, mata air Sodong dan Watubengkah di Desa Giriwungu, serta mata air Grigak di Desa Girikarto. Namun menurut Haryadi dan Sudarmadji (2014), tidak semua kelompok mata air di Kecamatan Panggang dapat memenuhi kebutuhan seluruh masyarakat. Beberapa mata air seperti mata air Kaligede, Sendangmulyo, Bibal, Sumber, Keluwih dan Beji memiliki potensi untuk memenuhi kebutuhan air masyarakat hingga tahun 2028 (Haryadi dan Sudarmadji 2014).

Mata air dapat diklasifikasikan berdasarkan debit dan pengalirannya. Debit air adalah jumlah atau volume air yang mengalir pada titik tertentu di sungai, saluran air, terusan atau mata air dalam satu kesatuan waktu, dinyatakan dalam satuan volume per detik ( $\mathrm{m}^{3} /$ detik) (Marbun 1982). Klasifikasi mata air berdasarkan debit air menurut Meinzer (1923) dalam Todd (1980) disajikan pada Tabel 1. 
Tabel 1. Klasifikasi mata air berdasarkan debit.

\begin{tabular}{cc}
\hline Kelas & Debit (liter/detik) \\
\hline I & $>10.000$ \\
II & $1.000-10.000$ \\
III & $100-1000$ \\
IV & $10-100$ \\
V & $1-10$ \\
VI & $0,1-1$ \\
VII & $0,01-0,1$ \\
VIII & $<0,001$ \\
\hline
\end{tabular}

Sumber: Meinzer (1923) dalam Todd (1980).

\subsection{Penampungan air hujan}

Upaya meminimalkan risiko kekeringan dilakukan oleh warga masyarakat dengan membuat bak Penampungan Air Hujan (PAH). PAH terdapat di Kecamatan Panggang Gunung Kidul. Haryadi dan Sudarmadji (2014) menyebutkan PAH dibangun dengan bantuan Uni Eropa pada tahun 2007 melalui program JRF (Java Reconstruction Fund) sebagai bentuk upaya untuk mengatasi kekeringan. PAH memiliki kelebihan yakni pengisian air mudah karena mengandalkan air hujan. PAH ini berfungsi untuk mengurangi ketergantungan masyarakat terhadap sumber mata air. Kualitas air yang ditampung setara dengan air yang berasal dari mata air.

PAH memiliki tiga komponen utama yaitu pengumpul air (atap), pipa/talang dan bak penampungan (Gambar 3). Atap rumah disarankan terbuat dari genteng dibandingkan dengan seng atau asbes. Hal tersebut karena jika terjadi pengikisan air, maka genteng menjadi material yang paling aman karena terbuat dari tanah liat. Salah satu sisi atap dibentuk miring menyerupai kerucut pada bagian ujung terdapat pipa yang berfungsi mengalirkan air menuju bak penampungan air. Semakin luas atap yang digunakan, semakin besar juga air yang akan ditampung. Perawatan diperlukan untuk mengecek terjadinya kebocoran pada talang maupun pada bak penampungan PAH.

PAH memiliki kelemahan yaitu keberadaannya terkadang cukup jauh dari masyarakat, sehingga dibutuhkan tambahan pipa untuk menyalurkan ke rumahrumah penduduk. Selain itu, hal ini hanya dilakukan pada salah satu bagian atap rumah saja akibat kondisi perekonomian masyarakat yang sebagian besar rendah, sehingga masih terjadi kekurangan meskipun sebetulnya bak penampungan sebagian besar telah mencukupi (Putra dan Hadi 2015). 


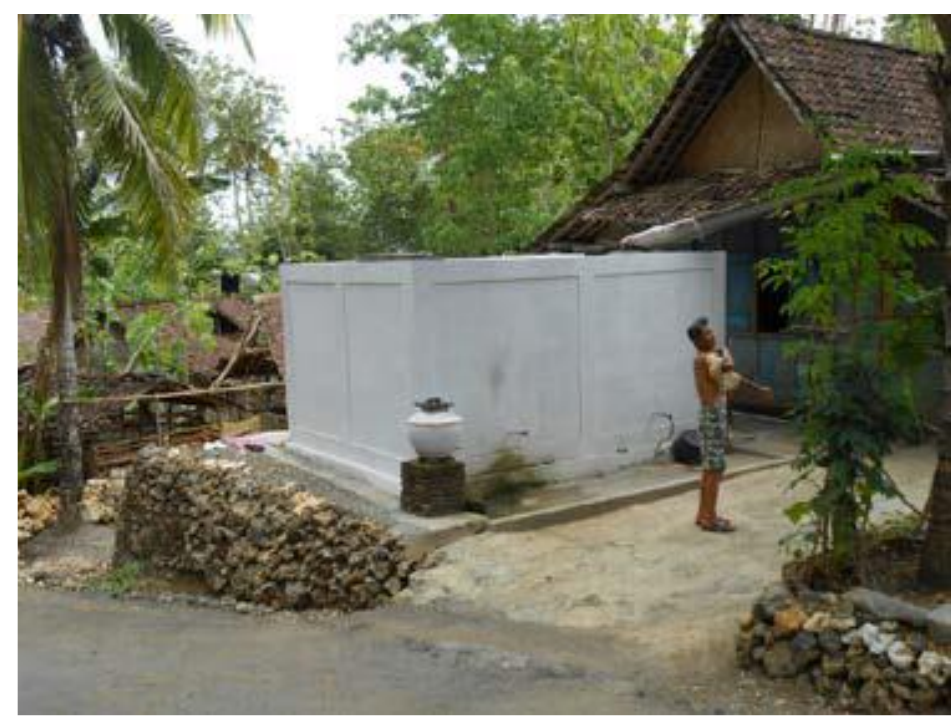

Gambar 3. Visualisasi PAH di Kecamatan Panggang.

(Haryadi dan Sudarmadji 2014)

\subsection{Pertanian tumpang sari}

Pertanian di Kabupaten Gunung Kidul dilakukan di tiga tempat yaitu di tegalan, sawah tadah hujan dan sawah irigasi. Pertanian merupakan kegiatan utama bagi sebagian besar penduduk yang tinggal di daerah berbukit dan lembah. Salah satu masalah utama yang dimiliki adalah tingkat ketersediaan air untuk tanaman. Masyarakat Kabupaten Gunung Kidul menyiasati hal tersebut dengan tumpang sari. Manfaat penanaman secara tumpang sari adalah tanaman akan dipanen secara bergilir ketika musim penghujan dan mengantisipasi gagal panen pada salah satu jenis tanaman dengan memiliki tanaman lainnya yang dapat dipanen. Dengan demikian, petani tetap dapat memperoleh penghasilan.

Pertanian tumpang sari adalah kegiatan pertanian yang mencampur dua jenis tanaman atau lebih di suatu lahan pertanian. Pola yang umum dilakukan dengan pergiliran pertanian seperti kedelai dan padi, serta penanaman bersama seperti padi, kacang tanah, jagung dan ubi kayu. Sistem tumpang sari digunakan untuk memanfaatkan jarak tanam guna meningkatkan pendapatan petani. Ginting dan Astuti (2018) melakukan penelitian dua jenis tumpang sari yaitu singkong-jagung-kedelai dan singkong-jagung-kacang tanah. Hasil penelitian menunjukkan bahwa tumpang sari singkong-jagung-kedelai lebih menguntungkan baik dari masa panen, aspek sosial, finansial dan pemasaran.

Upaya memaksimalkan hasil dari sistem tumpang sari adalah dengan melakukan penanaman di bawah naungan. Penelitian Ceunfin et al. (2017) menunjukkan bahwa penanaman tanaman jagung dan kedelai yang dilakukan di bawah naungan pohon kayu putih akan tumbuh lebih agresif dan kompetitif. 
Selain tumpang sari, warga juga memanfaatkan tanaman yang hidup di lembah dan tebing karst sebagai pemasukan tambahan seperti tanaman jati, akasia, mahoni dan sengon. Bagian bawah dari lereng ditanami rumput yang berfungsi sebagai pakan ternak.

\section{KESIMPULAN DAN SARAN}

Ketersediaan air sangat terbatas di Kabupaten Gunung Kidul yang merupakan daerah karst, terutama pada musim kemarau. Keberadaan mata air atau telaga masih belum cukup untuk memenuhi kebutuhan air. Upaya pemenuhan kebutuhan air masyarakat adalah dengan membuat pompa air sungai bawah tanah dan bak penampungan Air hujan (PAH). Pada kegiatan pertanian, strategi pertanian tumpang sari digunakan untuk mengatasi permasalahan ketersediaan air ini dan memaksimalkan hasil pertanian.

\section{DAFTAR PUSTAKA}

Antara News Yogyakarta. 2019. Sebanyak 355 telaga di Gunung Kidul kering [internet]. Tersedia di: https://jogja.antaranews.com/berita/386314/se banyak-355-telaga-di-gunung-kidul-kering.

[BBWS] Balai Besar Wilayah Sungai Serayu Opak. 2019. Upaya mengelola sumber daya air di Gunungkidul [internet]. Tersedia di: http://sda.pu.go.id /bbwsserayuopak/upaya-mengelola-sumber-daya-air-di-gunungkidul/.

Ceunfin S, Prajitno D, Suryanto P dan Putra ETS. 2017. Penilaian kompetisi dan keuntungan hasil tumpangsari jagung kedelai di bawah tegakan kayu putih. Savana Cendana 2(1):1-3.

Faizal R, Sismanto, Handayani R dan Asta. 2017. Pendugaan aliran sungai bawah tanah dalam pemenuhan kebutuhan air masyarakat Desa Hargosari Gunungkidul berdasarkan data VLF-EM terkoreksi topografi. Borneo Engineering: Jurnal Teknik Sipil 1(2):44-55.

Ginting H dan Astuti A. 2018. Prospek pengembangan usahatani tumpangsari tanaman pangan; singkong (Manihot esculenta) dan jagung (Zea mays) dengan tanaman lain di Kecamatan Semin, Kabupaten Gunungkidul. Jurnal Ilmiah Agritas 2(2):1-12.

Haryadi A dan Sudarmadji. 2014. Kajian potensi mataair di kawasan karst Gunung Kidul, kasus: Kecamatan Panggang. Jurnal Bumi Indonesia 3(3):110.

Karunia DN, Darsono dan Darmanto. 2012. Identifikasi pola aliran sungai bawah tanah di Mudal, Pracimantoro dengan metode geolistrik. Indonesian Journal of Applied Physics 2(2):91-101.

Marbun MA. 1982. Kamus geografi. Ghalia Indonesia. Jakarta. 
Putra AE dan Hadi MP. 2015. Evaluasi penampungan air hujan (PAH) untuk pemenuhan kebutuhan air domestik di Desa Giriharjo, Kecamatan Panggang Kabupaten Gunung Kidul. Jurnal Bumi Indonesia 4(1):158-166.

Sir MacDonald and Partners. 1979. Gunung Kidul groundwater project final report: geohydrology vol. 3A. Proyek Pengembangan Air Tanah (P2AT), Direktorat Bina Program Pengairan, Direktorat Jenderal Pengairan, Departemen Pekerjaan Umum. Yogyakarta.

Suarajogja.id. 2019. Kemarau panjang, 15 kecamatan di Gunungkidul terdampak kekeringan [internet]. Tersedia di: https://jogja.suara.com/read/2019/ 11/05/160610/kemarau-panjang-15-kecamatan-di-gunungkidul-terdam pak-kekeringan?page $=$ all.

Sunarto B. 1997. Hidrologi kawasan karst Gunung Sewu dan aspek-aspek yang berkaitan [Prosiding]. Seminar Hidrologi dan Pengelolaan Kawasan Karst. MAKARTI dan Fakultas Geografi UGM.

Suryanti ED, Sudibyakto dan Baiquni M. 2010. Strategi adaptasi ekologis masyarakat di kawasan karst Gunungsewu dalam mengatasi bencana kekeringan. Jurnal Kebencanaan Indonesia 2(3):658-674.

Todd DK. 1980. Groundwater hydrology $2^{\text {nd }}$ edition. John Wiley \& Sons. New York.

[UNDP] United Nations Development Programme. 2011. Mainstreaming drought risk management, a primer. UNDP. Nairobi

White WB. 1988. Geomorphology and hydrology of karst terrains. Oxford University Press. New York.

Wilhite DA. 2000. Drought preparedness and response in the context of subSaharan Africa. Journal of Contingencies and Crisis Management 8(2):8192. 